\title{
The Accounting Post-Employment Benefits Based on Actuarial Calculations
}

\begin{abstract}
Anna Cebotari
Department of Accounting, Audit \& Economic Analysis, Academy of Economic Studies of Moldova, Chisinau, Republic of Moldova

Email address:

annalungu@cartier.md

\section{To cite this article:}

Anna Cebotari. The Accounting Post-Employment Benefits Based on Actuarial Calculations. Humanities and Social Sciences. Vol. 6, No. 2, 2018, pp. 54-58. doi: 10.11648/j.hss.20180602.12

Received: February 9, 2018; Accepted: May 8, 2018; Published: May 28, 2018

Abstract: The accounting post-employment benefits based on actuarial calculations, at present remains a subject studied in Moldova only theoretically. Applying actuarial calculations of accounting in fact denotes its character of evolving. Because national accounting standards have been adapted to international, which in turn require the valuation of assets and debts at fair value, there is a need to draw up exact calculations on which stands the theory of probability and mathematical statistics. One of the main objectives of accounting information is reflected in its financial situations and providing internal and external users of the entity. Hence the need to reflect highly reliable information that can be provided by applying actuarial calculations. In this article is proposed methods of determining the pensions of employees in the case of the formation of the private pension fund. In fact, a private pension fund within the enterprise aims at motivating the employees to increase the quality of the manufactured products, the services rendered and the executed works. This article helps the entities to set up a private pension fund in the Republic of Moldova.
\end{abstract}

Keywords: Actuary, Retirement, Pension Plans, Defined Contribution Plans, Defined Benefit Plans

\section{Introduction}

In the current context market economy, actuarial calculations provided for generating financial information about development perspectives and future results of the company's activity. In part, related income of employees, actuarial calculations are oriented to providing the necessary information of managers, in order to evaluate and payments made to the pension fund allocations in view of many factors (inflation, unemployment, price dynamics securities, birth rate and mortality, etc.) for decision making related to the use of company resources on maintenance staff on retirement age and actual company cover the costs. Future spending should be subject to regular assessments. Hence the fact that actuarial calculations the employees' pension remain the supplier of information on strategic decisions related to expenditure on employees of the entity.

\section{Method}

Given that the Republic of Moldova isn't encountered in practice entities to constitute a private pension fund for employees, intend to address this issue. Entities, regardless of the activities are laid daily challenges of establishing a strategic system on rational expenditure management personnel remuneration, allowing the formation information on the growth and use of financial resources aimed at training in the company pension fund.

For these reasons, is recommend the use of International Accounting Standard 19, "Employee Benefits," in which they are exposed various aspects governing the recognition of expenditures on pension provision of personnel are set out, and International Accounting Standard 26 "Accounting and reporting of retirement benefit plans" to supplement International Accounting Standard 19 and which determines the rules for disclosure of information about pension plans in the entity's financial statements. Such an approach to the evidence of pension plans may raise interest for entities in different areas, as the specific examples presented and the actuarial calculation methods applied according to international accounting standards, gives the possibility of reflecting the financial means aimed at ensuring the staff with pensions and following the process of their training and use.

Actuary calculations represent all operations and norms on 
the basis of which, using statistical, mathematical and economic methods, financial calculations are made in insurance companies and not only [1].

In solving these problems, is propose the actuarial calculations, following the following principles:

1 Possibility and necessity of modeling. Actuarial evaluations related to the coverage of pension plans, but also their payments, are based on the correct reflection and traceability of financial sources, taking into account various factors - the price change in securities, inflation, unemployment, changes in cadres, etc.

2 Probability. The actuarial valuation of a model has a certain degree of acceptability of a fact or phenomenon. Thus, can speak of the fact that even if the pension plans were determined using actuarial mathematical calculus techniques, their value will still include a degree of uncertainty due to external factors.

3 Perspective. Actuarial calculations allow, because of their accuracy, to determine the amount of pension plans over a certain period of time. This allows the planning of future pension plans and the provisioning of related provisions.

4 Rationality of application. The actuarial assessment of pension plans must be clearly and concretely substantiated, without allowing errors to occur.

5 Periodicity. As the financial statements must reflect accurate information, actuarial calculations must be performed regularly over the same periods of time, typically at the end of the reporting period.

\section{Results and Discussions}

Following scientific research on this subject, in the conclusion that actuarial conventions are estimates made by the entity of the variables conditioned by the demographic and financial factors, which will determine the final expenses for the provision of compensations upon expiry of the work activity. There are two types of actuarial conventions [2]:

I. impartial, if done with a sufficient degree of caution

II. mutually compatible, if they reflect the economic relationship between factors such as inflation, rhythm of salary growth, profitability of pension plan assets and discount rates. In this case, the total amount of the pension plan's income can be determined only when the retired worker leaves the pension because there is an inaccuracy until the retired worker leaves the pension because the calculation formula itself is determined by the functional dependence of the amount of the retirement pension the size of the future pensioner's salary, and other variables [3].
The following formula is used to calculate the amount of the post-employment retirement benefit under International Accounting Standard 19 [4]

$$
\mathrm{Pt}=\mathrm{Xs}(\mathrm{Vp}-\mathrm{Vy}) * \mathrm{Sy}
$$

Where:

$\mathrm{Pt}$ - the total amount of the pension per specific year worked, lei;

Xs - percentage of wage, in percent;

$\mathrm{Vp}$ - retirement age, years;

$\mathrm{Vy}$ - the age from which the worker is entitled to retirement, years;

Sy - the amount of the salary before retiring, lei.

Is considered that such an approach is general in which actuarial estimation methods should be mentioned. Thus, when calculating the pension calculation method, only the volume of actual work and the current salary level are taken into account. When applying the method of estimating planned expenditures under the retirement plan, account is taken of the total expected workload that the worker will perform during his work experience in the company and the expected level of salary before he / she retires. Studies show that the company's debt on pension payments influences the magnitude of the calculated percentages of debt to employees on pensions.

Based on the above, the entity's liability on the employee's pension will be reflected in the financial statements at the expected amount that represents the amount of the expected future payment of the pension plan assets required to meet the obligations arising in respect of the services provided by the employees in the current period and the last period. The respective calculations for the determination of the pension retirement indemnity shall be drawn up for each individual employee.

Calculation of pension compensation according to the pension assessment method will be made by applying the formula:

$$
\mathrm{Pt}=\mathrm{Xs}(\mathrm{Vp}-\mathrm{Vy}) * \mathrm{Sy} * \mathrm{Ks}
$$

Where:

$\mathrm{Ks}$ - discount rate

Example

Suppose that Mr. Lungu Nicolai, is a participant in the retirement scheme. The salary calculated for the last years of activity is as follows: $2012-45000$ lei, 2013-50000 lei, 2014 - 48000 lei, 2015 - 54000 lei, 2016 - 60000 lei. The discount rate is $10 \%$.

The calculations based on these data are presented in Table 1.

\begin{tabular}{|c|c|c|c|c|c|c|}
\hline \multirow{2}{*}{ Year of management } & \multirow{2}{*}{ Salary, lei } & \multirow{2}{*}{ Discount rate, $\%$} & Ks & \multirow{2}{*}{ Xs, Percentage of salary } & \multirow{2}{*}{$\mathbf{V p}-\mathrm{Vy}$} & \multirow{2}{*}{ Pt, lei } \\
\hline & & & The coefficient of discount & & & \\
\hline 2012 & 45000 & 10 & 0.683013 & 0.1 & 1 & 3073.56 \\
\hline 2013 & 50000 & 10 & 0.751315 & 0.1 & 2 & 7513.15 \\
\hline 2014 & 48000 & 10 & 0.826446 & 0.1 & 3 & 11900.82 \\
\hline 2015 & 54000 & 10 & 0.909091 & 0.1 & 4 & 19636.37 \\
\hline
\end{tabular}

Table 1. Calculation of pension compensation according to calculated pension assessment method, lei. 


\begin{tabular}{llllllll}
\hline \multirow{2}{*}{ Year of management } & \multirow{2}{*}{ Salary, lei } & \multirow{2}{*}{ Discount rate, $\%$} & Ks & \multirow{2}{*}{ Xs, Percentage of salary } & Vp-Vy & Pt, lei \\
& & & & & & \\
& 60000 & 10 & 1 & - & 0.1 & 5 & 30000 \\
Total & 257000 & - & - & - & 30000 \\
\hline
\end{tabular}

Source: elaborated by author

The discount factor is determined as follows:

$\mathrm{Ks}=1 /(1+0.1)^{\mathrm{n}-1}$

According to the data, the total amount of the pension retirement pension calculated by the pension assessment method at the end of 2016 will amount to 30000 lei.

Calculation of the pension compensation according to the planned expenditure method calculated in stages:

Step 1) determine the value of current services for each year through the relationship:

$\mathrm{SC}=\mathrm{Xs}(\mathrm{N}-\mathrm{n}) * \mathrm{Sn}_{+1}(1+\mathrm{Ts})^{\mathrm{n}}$, where:

$\mathrm{SC}$ - the value of current services, lei;

$\mathrm{N}-\mathrm{n}$ - difference between previous and current years, years;

$\mathrm{Sn}_{+1}$ - the amount of future expenses, lei;

Ts - rate of discount, percentage

The necessary calculations are shown in Table 2.

Table 2. Calculation of the pension compensation according to the planned expenditure stage 1, lei.

\begin{tabular}{|c|c|c|c|c|c|c|}
\hline Period & Salary of future periods, lei & Discount rate, $\%$ & Ks, the coefficient of discount & Xs, the percentage of salary & $\mathbf{N}-\mathbf{n}$ & SC, lei \\
\hline 2012 & 60000 & 10 & 0.683013 & 0.1 & 1 & 4098.08 \\
\hline 2013 & 60000 & 10 & 0.751315 & 0.1 & 1 & 4507.89 \\
\hline 2014 & 60000 & 10 & 0.826446 & 0.1 & 1 & 4958.68 \\
\hline 2015 & 60000 & 10 & 0.909091 & 0.1 & 1 & 5454.55 \\
\hline 2016 & 60000 & 10 & 1 & 0.1 & 1 & 6000 \\
\hline Total & 300000 & - & - & - & - & 25019.2 \\
\hline
\end{tabular}

Source: elaborated by author

The expected amount of rewards for the retirement plan is determined in Table 3.

Step 2) determine the percentage value component (CPS)

$\mathrm{CPS}_{\mathrm{n}}=\mathrm{Ts} * \sum \mathrm{SC}_{\mathrm{n}}$ - the calculation of which is presented in Table 3 .

Table 3. Calculation of the expected amount of retirement plan reimbursement, lei.

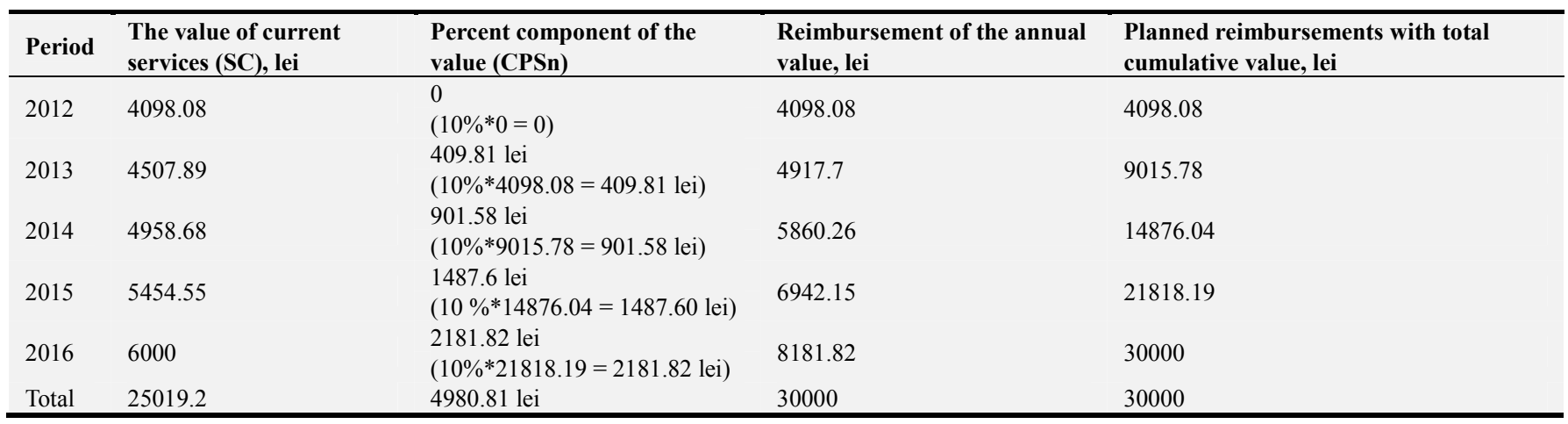

Source: elaborated by author

Stage 3) Determine the amount of profit on the plan assets and its effect on the pension plan expenditures. That provisioning now will ensure the execution of the pension plan in the future. A successful calculation of these expenditures will reduce the total cost of the pension plan, especially if the investment income obtained is higher than expected.

Let us admit that according to the Accounting Policies of the „Y” entity, the expected revenue for 2013 will be $4 \%$, for 2014 - 7\%. The real income for these periods was 150 lei and 1200 lei, respectively (table 4).

Table 4. Determination of actuarial profit (loss).

\begin{tabular}{lll}
\hline \multirow{2}{*}{ Actuarial gains / losses } & Period & $\mathbf{2 0 1 4}$ \\
\cline { 2 - 3 } & $\mathbf{2 0 1 3}$ & 631.1 \\
\hline The expected actuarial income, lei & 163.92 & -568.9 \\
Actuarial gain (loss), lei & 13.92 & 5798.06 \\
Total expenditures on the pension plan, lei & 4767.7 & $(4958.68+901.58-631.10+568.90)$ \\
\hline
\end{tabular}

Source: elaborated by author

Actuarial gain or loss may occur as a result of the change in either the expected amount of the pension plan or the 
amount of expected earnings in relation to the pension plan.

The main reasons for recognizing actuarial profit or loss may be:

1) unplanned staff turnover, early retirement or employee death, prizes or cost of medical services

2) changing the method of calculating future pension plans

3 ) changing the calculation of the expected value

4) the difference between the actual income and the expected income from the provisioning for the pension plan

With time, actuarial income and losses can be settled with each other. In this way, the reward value for retirement should be seen as a diapason (called a corridor) as high as possible to the real value of pensions. The Company may recognize the actuarial gain or loss that integrates into this range but is not required.

International Accounting Standard 19 requires entities to recognize actuarial gain or loss that does not integrate into the range of more than $10 \%$. In other words, the entity shall recognize a specified proportion of net cumulative actuarial gains and losses that exceeds more than:

1. $10 \%$ of the present value of the defined benefit obligation (before deducting the plan assets); and

2. $10 \%$ of the fair value of any plan assets.
The proportion of actuarial gains and losses to be recognized for each defined benefit plan is the surplus that is out of the "corridor" limit of $10 \%$ on the previous reporting date, divided by the predicted average, of the remaining work time of the employees participating in the plan [4].

It also allows the application of systematic rapid recognition methods, assuming the same basis is applied to both gains and losses, and the basis is consistently applied from one period to the next. Such permitted methods include the immediate recognition of all actuarial gains and losses.

Stage 4) determines the value of services rendered in the past

The calculation of this expenditure is necessary when:

1) the employer grants the right to retirement insurance for employees who worked for entity until it has approved a retirement plan,

2 ) the entity increases the amount of the pension calculated for past periods.

Let's admit that the entity approved another pension plan for 2014 , and that $20 \%$ of this year's pension calculation. Thus, the employee will change the value of current services for the coming years.

The respective calculations with the change of the pension plan are presented in Table 5.

Table 5. Calculation of expenditure on the pension plan, lei.

\begin{tabular}{llllll}
\hline Year of management & SC & $\mathbf{C P S}_{\mathbf{n}}$ & $\begin{array}{l}\text { Actual actuarial } \\
\text { income }\end{array}$ & $\begin{array}{l}\text { Reimbursement of the } \\
\text { annual value }\end{array}$ & Planned reimbursements for accrued value \\
\hline 2012 & 4098.08 & 0 & & 4098.08 & 4098.08 \\
2013 & 4507.89 & 409.81 & 150 & 4767.7 & 8865.78 \\
2014 & 9917.35 & 886.58 & 1200 & 9603.93 & 18469.71 \\
2015 & 10909.09 & 1876.97 & & 12786.15 & 31255.77 \\
2016 & 12000 & 3155.58 & & 15155.58 & 46411.35 \\
Total & 41432.41 & 6328.94 & -1350 & 46411.35 & 46411.35 \\
\hline
\end{tabular}

Source: elaborated by author

According to the calculations, the following transactions will be recorded in the entity's accounting (assuming we will make the accounting records for 2013):

1) Recognition of the expenses related to the employee's reward according to the expected value 4917.70 lei $(4507.89+409.81)$

Debit, Expenses on Employee Rewards "-4917.70 lei

Credit, Retirement Debt "- 4917.70 lei

2) Reflecting the reduction in the level of spending on retirement rewards in the investment account

Debit, Pension Retirement Debt - 163.92 lei

Credit, Expected Revenue for Plan assets "- 163.92 lei

3) Recognition of actuarial losses

Debit, Pension Retirement Debt - 13.92 lei

Credit, actuarial profit on plan assets - 13.92 lei

The disclosure in International Accounting Standard 19 of the amount of liabilities in respect of the defined benefit pension plans is as follows.

Let's assume that the $\mathrm{Y}$ entity reflected in the balance sheet at the end of 2015 the pension debt in the amount of $150 \mathrm{mln}$. Lei. On 1-st January, 2016 the management of the entity took the decision to move to the pension insurance scheme on the established payment plan, on the increase in the amount of the calculated pension. The expected debt amount at 31 December, 2015 is 500 million. Lei, and the real value is $450 \mathrm{mln}$. Lei. Additional reward is determined in the size of $50 \mathrm{mln}$. Lei.

The payment of the guaranteed pension is after 8 years of service to the entity, and on the date of the increase is guaranteed payment of $1 / 5$ of the total amount of the debt of the previous year.

Using the above data, can be calculated the actuarial loss or profit, tested on the $10 \%$ corridor proposed by the standard (Table 6).

The calculation of the entity's debt based on these data is presented in Table 6 .

Table 6. Determination of the debt value in respect of the pension plan as of 31.12.2016 of the entity Y."

\begin{tabular}{ll}
\hline Retirement plan indices & Index size \\
\hline The expected debt amount at 31.12.2015, mln. Lei, & 500 \\
Actual debt, mln. Lei & 450 \\
Transaction debt, mln. Lei & 60 \\
Recognized debt, mln. Lei & 150 \\
Increase in debt, mln. Lei & -90 \\
Actuarial loss, mln. Lei, & 50 \\
10\% of the actual debt (coredor), mln. Lei & 45 \\
Actuarial profit over the corridor, mln. Lei, & 10 \\
Retirement period within the company, years & 8 year \\
\hline
\end{tabular}




\begin{tabular}{ll}
\hline Retirement plan indices & Index size \\
\hline $\begin{array}{l}\text { Actuarial income recognized in financial statements (10 } \\
\text { million lei / 8 years), mln. Lei, }\end{array}$ & 1.25 \\
\hline
\end{tabular}

Source: elaborated by author

According to International Accounting Standard 19, the entity will recognize the decrease in debt of 90 million. lei immediately or may recognize this decrease as income on a prorata basis over a certain period of time but no more than 5 years.

In order to have actual results from the calculations performed, the entity must also take into account a number of factors such as inflation, return on investment, unemployment, mortality and birth rate, and so on. Thus actuarial calculations come to reduce the risk of mistakes that can be made in the calculation of the pension plan for each individual employee, especially in the Republic of Moldova.

Information on the debts of pension plans should be disclosed in the financial statements, is annex to the Financial Report should be introduced for a more rigorous evidence. For paid retirement plans, the company will have to disclose the following information:

1) the entity's accounting policies, on how to recognize actuarial gains or losses,

2) the overall feature of the entity's pension plan,

3 ) the breakdown of the assets and liabilities of the balance sheet,

4) the amounts included in the fair value estimation of assets,

5) detailing changes in the net amount of debt over the period of management reflected in the balance sheet.

In accordance with International Accounting Standard 26, the ratio of a defined benefit plan should either:

(a) a situation that highlights:

(I) net assets available for benefits;

(II) the actuarial value of promised retirement benefits, distinguishing the legitimate and non-legitimate benefits; and

(III) the resulting surplus or deficit; or

(b) a statement of net assets available for benefits, comprising either:

(I) a note showing the actuarial value of promised retirement benefits, distinguishing between legitimate benefits and those that are not legitimate; or

(II) a reference to this information in an attached actuarial report [5].

If an actuarial valuation has not been prepared at the date of the report, the most recent valuation shall be used, specifying the date on which it was carried out.

\section{Conclusions}

The entities of the Republic of Moldova do not practice the establishment of the pension fund within the company for the payment of their employees' pensions. This practice is commonplace in developed countries, where employees are protected by employers even during their retirement. Actuarial evaluations come to determine the fair value of post-employment benefits. In developed countries, actuarial valuation is a standard practice. International Accounting Standard 19 does not oblige the entity to employ an actuary to carry out the valuations, these calculations can be made by the company's specialists if they have knowledge in the field. Actuarial calculations for pension plans based on the information received enable the changes in the assets and liabilities of the retirement benefit plan to be determined over the medium and long-term, in relation to the decision-making of the entity for the post-employment benefit payments.

The accuracy of the data obtained from actuarial valuations gives the opportunity to present fair information in the financial statements and compliance with the accounting principles - a fundamental objective of accounting. In European countries, the principle of fair image is the basis for accounting evidence. Thus, the actuarial valuations undertaken by the company, if taken with the utmost care, will provide a degree of confidence to the users of information.

\section{References}

[1] Viorel ȚURCANU, Irina GOLOCEALOVA, Raportarea Financiara conform standardelor internationale, ACAP, Chisinau 2015, 450 p.

[2] Аверчев И. В. МСФО.1000 примеров применения, Москва, Издательство: Рид Групп, 2011, 992 р.

[3] Фонд КМСФО: Учебные материалы по МСФО, Web: www.ifrs.org.

[4] IAS 19 „Beneficiile angajaţilor”, în: Monitorul Oficial al RM, nr. $237-240$ din 31.12 .2008 .

[5] IAS 26 „Contabilizarea şi raportarea planurilor de pensii”, în: Monitorul Oficial al RM, nr. 237-240 din 31.12.2008.

[6] S. N. C., Capital propriu și datorii”. În Monitorul Oficial al RM, nr. 233-237 din 22.10.2013.

[7] De Roode. Pensions as Wages / A. De Roode // American Economic Review. 1913. - Vol. June.- P. 287-295.

[8] Dewhirst J. F. A conceptual approach to pension accounting / J. F. Dewhirst // The Accounting Review. 1971 - Vol. April. P. $365-373$.

[9] Hannah L. Inventing Retirement: The Development of Occupational Pensions in Britain / L. Hannah // Cambridge: CUP, 1986. $-216 \mathrm{p}$.

[10] Chandar N. The development of actuarial-based pension accounting at the Bell System, 1913-40 / N Chandar, P. J. Miranti // Accounting History. 2007. - Vol. 2. - P. 205-234.

[11] 2018 Actuarial Report. Minister of Public Works and Government Services, Canada, 2018, ISSN 2291-7950.

[12] Final 2018 Actuarial Value Calculator Methodology, Centers for Medicare \& Medicaid Services Center for Consumer Information \& Insurance Oversight. 2016.

https://www.cms.gov/CCIIO/Resources/Regulations-andGuidance/Downloads/Final-2018-AVC-

Methodology121616.pdf. 